
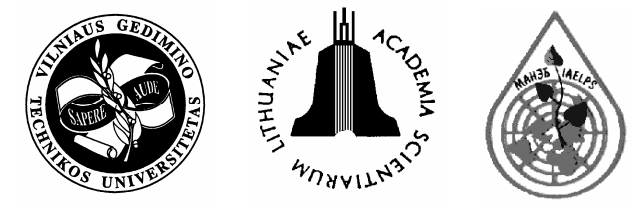

\title{
RADIOLOGICAL INVESTIGATION OF ROACH AND PERCH FROM SOME LAKES IN LITHUANIA
}

\author{
Violeta Čepanko ${ }^{1}$, Raimondas Leopoldas Idzelis ${ }^{1}$, Vytautas Kesminas ${ }^{2}$, Rima Ladygienè ${ }^{1,3}$ \\ ${ }^{1}$ Dept of Environmental Protection, Vilnius Gediminas Technical University, \\ Saulètekioal.11,LT-10223Vilnius,_Lithuania.E-mail:aak@ap.vtu.lt,cz.violeta@gmail.com \\ ${ }^{2}$ Sector of Freshwater Ecology, Laboratory of Ecology and Physiology of Hydrobionts, \\ Dept of Aquatic Ecosystems, Institute of Ecology, Vilnius University, \\ Akademijos g.2,LT-08412 Vilnius,Lithuania.E-mail:v.kesminas@takas.lt \\ ${ }^{3}$ Radiation Protection Centre, Kalvariju g. 153, LT-08221 Vilnius, Lithuania.E-mail: r.ladygiene@rsc.lt.
}

Submitted 20 Apr 2006; accepted 10 Oct 2006

\begin{abstract}
From the point of view of biological toxicity the most toxic radionuclides are man-made ${ }^{90} \mathrm{Sr}$ and ${ }^{137} \mathrm{Cs}$ because the behavoir of both of them is similar to stable calcium and potassium in the body. Fish is the last part of the hydrosystem chain which accumulates pollutants. The aim of this study was to analyse the distribution of these two radionuclides in the muscle and other organs of perch and roach that differ by age and living conditions. Measurements were performed for ${ }^{137} \mathrm{Cs}$ and ${ }^{90} \mathrm{Sr}$ activity concentrations in fishes from the lakes of Drūkšiai, Lūkstas and Dusia. Radioecological investigation was carried out for different age groups of roach and perch analysing samples of muscle and spine bones (including the head of fish). Radioecological investigation of fishes from the lakes of Drūkšiai, Lūkstas and Dusia show that the activity concentrations of ${ }^{137} \mathrm{Cs}$ and ${ }^{90} \mathrm{Sr}$ are low. Anyway, the accumulated radioactivity by food chain reaches the human body. Nowadays a lot of investigations are related to the lakes in the vicinity of Ignalina NPP. The investigation shows that the activity concentrations of ${ }^{137} \mathrm{Cs}$ and ${ }^{90} \mathrm{Sr}$ in fishes from the Drūkšiai lake are the same as in fishes from other lakes in other locations of Lithuania.
\end{abstract}

Keywords: fish, Lithuania, radioecology, radionuclide, toxity, trophic chain.

\section{Introduction}

The whole nature is constantly affected by radionuclides of cosmic origin and those from the Earth's crust. However, only after the use of radioactivity for medical and industrial purposes, after nuclear bomb tests the radiation protection measures started to be implemented. After releases of man-made radionuclides to the environment humans realized that this may be the reason for cancer, genetic disturbances and other diseases [1].

Man-made radionuclides appeared in the environment after the first nuclear bomb tests in the atmosphere, later - during operation of nuclear installations and accidents at nuclear power plants. Long-lived radionuclides are the most dangerous from the point of view of the ecology. Food products are connected with the environment by a food chain which is shorter for vegetables and longer for meat, milk or fish. All food products are connected in different ways with the components of the environment: air, water, soil and plants growing in the soil. The way of behavior of two of long-lived radionuclides ${ }^{90} \mathrm{Sr}$ (strontium) and ${ }^{137} \mathrm{Cs}$ (cesium) - is the same as their stable isotopes calcium and potassium that are in the human body.
There exist at least three the most important sources of contamination of the environment with ${ }^{90} \mathrm{Sr}$ and ${ }^{137} \mathrm{Cs}$. The first one is connected with tests of nuclear bombs.

The first tests of nuclear bombs were performed in Japan in 1945. According to the data of the United Nations Scientific Committee on the Effects of Atomic Radiation (UNESCAR 1993) during the period before 1962, when a triangular moratorium was signed by the Soviet Union, USA and United Kingdom for the restriction of nuclear tests in the atmosphere, already 360 nuclear bomb tests were performed. During these tests releases to the environment were up to $0,76 \mathrm{EBq}\left(0,76 \times 10^{18} \mathrm{~Bq}\right)$ of ${ }^{90} \mathrm{Sr}$ and $1,14 \mathrm{EBq}$ of ${ }^{137} \mathrm{Cs}$. Most of these releases deposited in the North hemisphere, close to the $40^{\circ}$ latitude, less part of releases deposited close to the North Pole and direction to the equator. Only one third of all the releases deposited in the South hemisphere.

The next source of contamination of the environment with ${ }^{90} \mathrm{Sr}$ and ${ }^{137} \mathrm{Cs}$ is releases from nuclear installations and nuclear reprocessing plants. Low-level radioactive waste was released from Sellafield nuclear fuel reprocessing facility to the Irish Sea. During the period $1950-1990$ about $3-4 \times 10^{16} \mathrm{~Bq}$ of ${ }^{137} \mathrm{Cs}$ was released from this installation [2]. 
One more source of contamination of the environment are accidents at nuclear power plants and nuclear reprocessing plants. Paper [2] stales hat release during accidents are smaller than from nuclear bomb tests. Releases of ${ }^{137} \mathrm{Cs}$ during the accident at Chernobyl NPP were approximately about $100 \mathrm{PBq}\left(1 \mathrm{P}=10^{15}\right)$ or 20 $40 \%$ of the whole content of ${ }^{137} \mathrm{Cs}$ which was in the active zone of the reactor [3], and approximately about $8 \mathrm{PBq}$ of ${ }^{90} \mathrm{Sr}$. One third of all these releases deposited in the European part of the territory of the Soviet Union approximately $30 \mathrm{PBq}$ of ${ }^{137} \mathrm{Cs}$ and approximately $90 \%$ of ${ }^{90} \mathrm{Sr}(7 \mathrm{PBq})$ [4]. Paper [5] states that the density of precipitation of ${ }^{137} \mathrm{Cs}$ in Lithuania was less than $18,5 \mathrm{kBq} / \mathrm{m}^{2} .{ }^{137} \mathrm{Cs}$ activity concentrations in the soils of Lithuania were measured in 1992 dividing the territory into sectors of $16 \times 16 \mathrm{~km}$ [5]. Sampling was performed up to a depth of $5 \mathrm{~cm}$. Three cesium "spots" were estimated where ${ }^{137} \mathrm{Cs}$ activity concentrations were the highest in the southern and western parts of Lithuania and the Curonian Spit. The highest activity concentration in the soil was measured in 1992 in the samples from the Curonian Spit - approximately $19700 \mathrm{~Bq} / \mathrm{m}^{2}$. Activity concentrations were measured at the same time in the samples of the other two "spots". The highest activity concentration of ${ }^{13 \mathrm{~T}} \mathrm{Cs}$ was measured $-1600 \mathrm{~Bq} / \mathrm{m}^{2}[5,6]$.

The influence of radionuclides on the environment and its components is different. The influence of some of the radionuclides was estimated. However, it varied in time or depended on local conditions. Dose estimation of all possible sources is important for the population [7].

Radiation protection is based on the principle that if human life is safe, it means that all nature is safe as well. The whole live nature should be protected from extinction.

Some years ago the problem started to be analysed is such a behavior of humans right: are radiation protection measures appropriate for all living organisms if these measures are suitable for humans? That is a subject for discussions. It is evident that some kinds of plants and animals are more sensitive to radiation than humans, therefore, radiation can have negative effects on them. Having decided that the environment is safe for a human, it is necessary to evaluate if the same environment is safe for biota [8].

In general, all living organisms within the ecosystem exist in an equilibrium and outside the ecosystem within all environment components as well. The ecosystem is typically open system, for some scale within the self-control, so the appearance of new environment factors can lead to the catastrophic consequents, and sometimes fully ruin the ecosystem and eliminate her some primary classes.

Some pass ways exist for the migration of radionuclides from the water systems to the human body. Most important of them is water-fish-human pass way. The fish is the last trophic link of the hydrosystems and eventual biological product of water and the best accumulate of contaminants in the water. From the view of the biological toxicity the most toxic radionuclides are man-made ${ }^{90} \mathrm{Sr}$ and ${ }^{137} \mathrm{Cs}$ because the behaviour of both of them are similar as stable calcium and potassium in the body [9, 10].

The main task of the radiological investigations in nowadays is evaluation of the behavior of the radionuclides released worldwide to the ground and water systems, evaluation of the levels of accumulation and distribution of radionuclides within ecosystems of land and water, evaluation of the peculiarities of their migration by the food chain [9, 11]. Radioecological monitoring of lakes started in Lithuania in 1993. For the control of population some kinds of fish were selected [10] - perch and roach, so that kinds were selected for analysis within this work. Radioecological research was organized and performed by the scientists of Institute of Ecology and Ministry of Environment during the period 1995-1997. Later only separate measurements were performed. So, the database is updated not systematically and the research is relevant.

The aim of this study was to analyse the distribution of two man-made radionuclides ${ }^{137} \mathrm{Cs}$ and ${ }^{90} \mathrm{Sr}$ in the muscle and other organs (bones) of roach (Rutilus rutilus) and perch (Perca fluviatilis) that differ by age and living conditions in the lakes of Drūkšiai, Lūkstas and Dusia.

\section{Methodology of investigation}

Sampling and investigation on site were performed during 2005 in three lakes of Lithuania - the Drūkšiai, the Lūkstas and the Dusia (Fig1). Ecological, hydrological and thermal conditions varied in the investigated lakes. The Drūkšiai is deep, thermostable, the Dusia is medium deep and thermostable and the Lūkstas is shallow and thermounstable [12, 13]. The Drūkšiai is a cooling basin for Ignalina Nuclear Power Plant, therefore, thermocondition changed dramatically, towards temperature increase [14]. These lakes are monitored periodically.

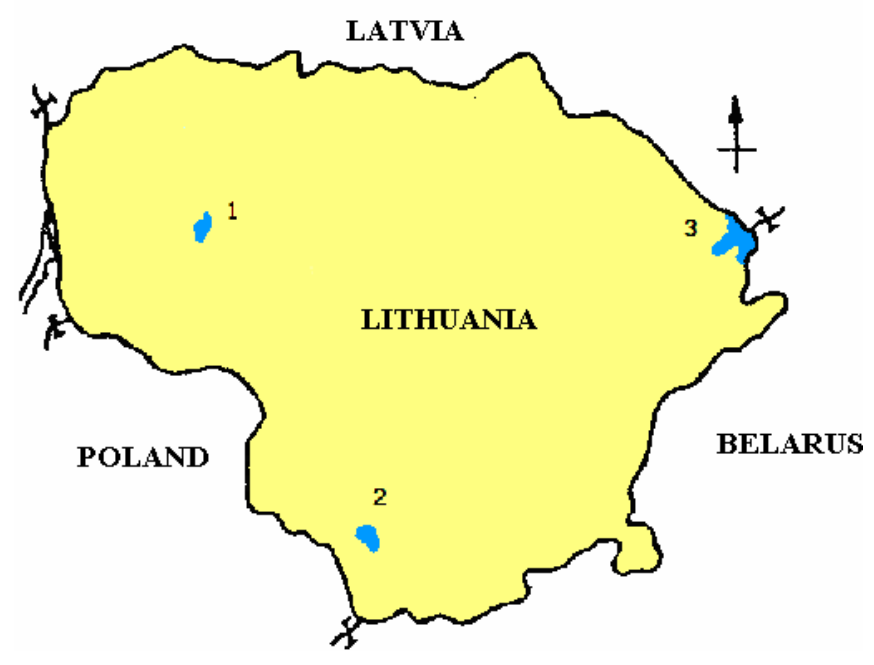

Fig 1. Location of lakes where sampling of fish was performed: 1 - the Lūkstas, 2 - the Dusia, 3 - the Drūkšiai

Sampling of fish was performed during the ichthyology expeditions in July-September 2005. The parts of fish investigated were muscle and bones. Sampling quantity was higher using 20 fishes of one kind (and of 
different age groups if it was possible) from each lake. All measured fishes were divided into two age groups: group I - 4-7 year old fishes, group II - 8-11 year old fishes. The weight of a sample for muscles was 1,0$1,5 \mathrm{~kg}$, and for bones (including fish head) - corresponding to muscles taken for a sample. The fish was sampled using porosity fishing nets. Generally they were of the same type, high and porosity. The ichthyological analysis of the fish sampled during expeditions was performed in the Laboratory of Ecology and Physiology of Hydrobionts at Institute of Ecology of Vilnius University using universal well-known methods of Pravdin and Thoresson $[15,16]$.

Measurements of activity concentrations of ${ }^{137} \mathrm{Cs}$ and ${ }^{90} \mathrm{Sr}$ were performed at Radiation Protection Centre. For the radiological analysis of ${ }^{137} \mathrm{Cs}$ and other radionuclides $\left({ }^{40} \mathrm{~K}\right)$, estimates were performed with a high-purity germanium detector gamma spectrometer using mathematical calibration software ISOCS/labSOCS. For estimating ${ }^{90} \mathrm{Sr}$, a liquid scintillation counter Quantulus was used. Before counting sample preparation was performed: drying a sample at $105^{\circ} \mathrm{C}$ temperature for a constant weight, after that its ashing for 3 hours at $310^{\circ} \mathrm{C}$ temperature and for 15 hours at $610^{\circ} \mathrm{C}$ temperature. Activity concentration of ${ }^{137} \mathrm{Cs}$ and ${ }^{40} \mathrm{~K}$ was measured in the ash of a sample.

Estimate of ${ }^{90} \mathrm{Sr}$ was performed after radiochemical separation of ${ }^{90} \mathrm{Y}$ (which is a daughter of ${ }^{90} \mathrm{Sr}$ and is in equilibrium) from the ash of a sample. For the separation, a $10 \%$ HDEHP (di(2)-etil-heksil) phosphoric acid solution in toluene was used $[17,18]$.

\section{Results and discussion}

The results of analysis show that the activity concentration of radionuclides is based on the consistent pattern of accumulation of the radionuclides due to the processes of adsorption and metabolism. The behaviour of ${ }^{90} \mathrm{Sr}$ in a body is the same as that of stable calcium, and it accumulates in bone tissues, when the behaviour of ${ }^{137} \mathrm{Cs}$ is the same as that of calcium, and it accumulates in the muscles, so the distribution of it in a body is more or less the same [9].

Investigation of accumulation of ${ }^{137} \mathrm{Cs}$ (a part of which is in the ion form in water) in the muscles of fishes from the lakes of Drūkšiai, Lūkstas and Dusia gives results that an average activity concentration in predatory fishes (perch) is $1,9-2,6 \mathrm{~Bq} / \mathrm{kg}$, and the value is higher than in the samples of nonpredatory fishes (roach) - 0,4$1,2 \mathrm{~Bq} / \mathrm{kg}$ (Table 1).

Fig 2 shows that the highest ${ }^{137} \mathrm{Cs}$ activity concentration was measured in the muscles and bones of the perch from the Lūkstas, so it is evident that the western part of Lithuania was stronger contaminated by the passing radioactive cloud after the accident at Chernobyl NPP. The investigation results show that the distribution of ${ }^{137} \mathrm{Cs}$ in the muscles and bones of the fish is homogenous and does not depend on its kind [9]. Table 1 and Fig 2 confirm this conclusion. ${ }^{137} \mathrm{Cs}$ is accumulated in the muscles $(9-56 \%)$ but not in the bones $(5-35 \%)$.

The difference of accumulation of ${ }^{90} \mathrm{Sr}$ in different kinds of fish (predatory and nonpredatory) was determined especially in the fish bone samples (Fig 2), when a higher difference of the accumulation of ${ }^{137} \mathrm{Cs}$ was found in the muscles of fish irrespective of the food of fish. A higher difference was found in the fish samples from the Lükstas. The values of ${ }^{137} \mathrm{Cs}$ activity concentrations in the fish muscles, Bq/kg of net weight, are shown in Fig 3 .

During biological migration of ${ }^{90} \mathrm{Sr}$ in water association this radionuclide is eliminated from fish muscles. However, releases of ${ }^{90} \mathrm{Sr}$ to the environment distribute this migration, and ${ }^{90} \mathrm{Sr}$ is accumulated in fish bones. It was estimated after analysing samples of very young fishes from the Drūkšiai. An average activity concentration of ${ }^{90} \mathrm{Sr}$ in the muscles of roach was $1,31 \pm 0,34 \mathrm{~Bq} / \mathrm{kg}$ of net weight, and it is twice higher than that in the fish samples from the lakes of Dusia and Lūkstas. An average activity concentration of ${ }^{90} \mathrm{Sr}$ in the bone samples was

Table 1. Average activity concentrations of ${ }^{137} \mathrm{Cs}$ and ${ }^{90} \mathrm{Sr}$ in fish tissues, $\mathrm{Bq} / \mathrm{kg}$ of net weight

\begin{tabular}{|c|c|c|c|c|}
\hline Kind of fish & Tissue & $\begin{array}{c}\text { The number of fishes in } \\
\text { a sample }\end{array}$ & ${ }^{90} \mathrm{Sr}$ & ${ }^{137} \mathrm{Cs}$ \\
\hline \multicolumn{5}{|c|}{ The Dusia } \\
\hline \multirow{2}{*}{ Roach } & muscles & \multirow{2}{*}{24} & $0,5 \pm 0,1$ & $1,2 \pm 0,2$ \\
\hline & bones & & $3,0 \pm 0,6$ & $1,0 \pm 0,3$ \\
\hline \multirow{2}{*}{ Perch } & muscles & \multirow{2}{*}{32} & $0,1 \pm 0,1$ & $1,9 \pm 0,1$ \\
\hline & bones & & $0,2 \pm 0,3$ & $1,2 \pm 0,1$ \\
\hline \multicolumn{5}{|c|}{ The Drūkšiai } \\
\hline \multirow{2}{*}{ Roach } & muscles & \multirow{2}{*}{30} & $0,8 \pm 0,2$ & $0,7 \pm 0,1$ \\
\hline & bones & & $5,7 \pm 1,2$ & $0,4 \pm 0,1$ \\
\hline \multirow{2}{*}{ Perch } & muscles & \multirow{2}{*}{15} & $1,2 \pm 0,3$ & $2,0 \pm 0,4$ \\
\hline & bones & & $3,2 \pm 0,7$ & $1,3 \pm 0,2$ \\
\hline \multicolumn{5}{|c|}{ The Lūkstas } \\
\hline \multirow{2}{*}{ Roach } & muscles & \multirow{2}{*}{36} & $0,8 \pm 0,3$ & $0,6 \pm 0,1$ \\
\hline & bones & & $1,8 \pm 0,6$ & $0,4 \pm 0,2$ \\
\hline \multirow{2}{*}{ Perch } & muscles & \multirow{2}{*}{34} & $0,3 \pm 0,1$ & $2,6 \pm 0,5$ \\
\hline & bones & & $0,5 \pm 0,2$ & $1,8 \pm 0,3$ \\
\hline
\end{tabular}



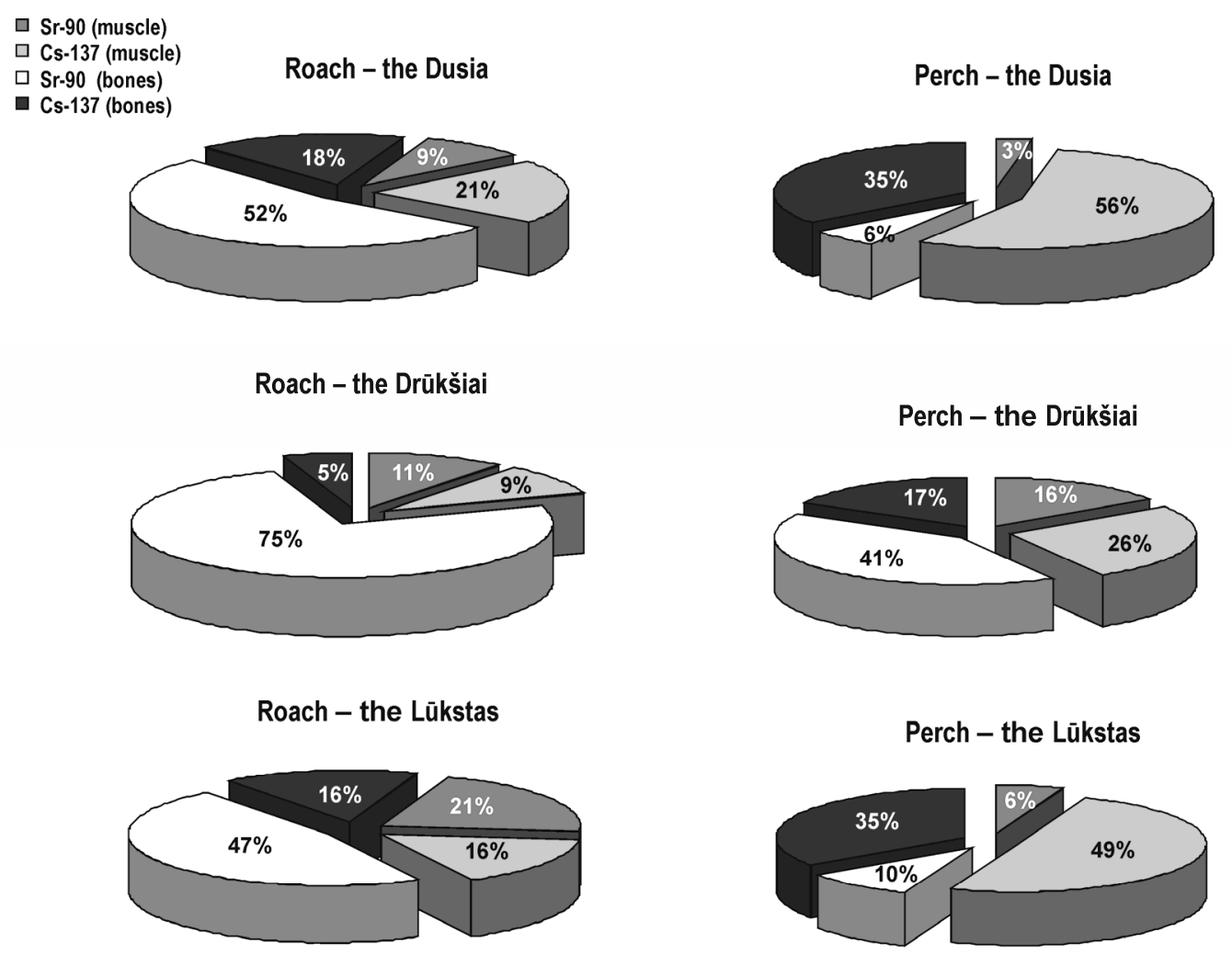

Fig 2. Distribution of ${ }^{137} \mathrm{Cs}$ and ${ }^{90} \mathrm{Sr}$ activity concentration in the muscles and bones of perch and roach from the lakes of Dusia, Drūkšiai and Lūkstas, in percent

$6,54 \pm 1,3 \mathrm{~Bq} / \mathrm{kg}$ of net weight. These results show that the Drūkšiai is more contaminated than the other two lakes (Figs 4, 5). The elevated concentrations of radionuclides could be explained as a consequence of significant changes in the patterns of lake thermoregime. Because of water temperature increase in the Drūkšiai the majority of fish species population were affected, and their population parameters changed [14]. As established, the main cause was longer active during the fish feeding period which caused a more intense deposition of radionuclides in all the fish species, especially in predatory fishes. It should be mentioned that during their migration in the environment radionuclides are affected by different factors, and changes of their chemical form are possible [19, 20].

The investigation results show that accumulation of ${ }^{137} \mathrm{Cs}$ in roach does not depend on the fish age (Fig 5).

In the case of perch accumulation of ${ }^{137} \mathrm{Cs}$ increases with the fish age. It was also estimated by different scientists [9, 21, 22, 23]. The level of increase in accumulation of ${ }^{137} \mathrm{Cs}$ with the fish age is explained by the fact that the food of predatory fish kinds is more contaminated by ${ }^{137} \mathrm{Cs}$ than the food of nonpredatory fishes (Figs 3 and 5).

According to estimations, ${ }^{90} \mathrm{Sr}$ activity concentrations in the fish bones analysed are 2,5 times higher than those in the muscles (Table 1, Fig 2). During cooking ${ }^{90} \mathrm{Sr}$ moves to the liquid part of the food, so it can be taken to the human body [16]. The highest ${ }^{90} \mathrm{Sr}$ activity concentration was determined in the roach bones (Fig 5). Approximately $90 \%$ of ${ }^{90} \mathrm{Sr}$ is in a soluble form in the
Drūkšiai [11], so it can be explained that the values in the fish samples from this lake are higher.

It was estimated that an average activity concentration of ${ }^{90} \mathrm{Sr}$ in the muscles of nonpredatory fishes was higher than that in predatory ones (the lakes of Lūkstas and Dusia). However, the highest activity concentration of ${ }^{90} \mathrm{Sr}$ was found in the muscles of perch $(1,31 \pm 0,34 \mathrm{~Bq} / \mathrm{kg}$ of net weight).

Radiological investigation showed that the levels of contamination of fish by ${ }^{137} \mathrm{Cs}$ and ${ }^{90} \mathrm{Sr}$ are not high, although the possibility to be taken to the human body exists, especially for people that eat a lot of fish.

\section{Conclusions}

1. Activity concentration of ${ }^{137} \mathrm{Cs}$ in the muscles of predatory fishes from the lakes of Drūkšiai, Lūkstas and Dusia was in the range $1,39 \div 3,16 \mathrm{~Bq} / \mathrm{kg}$ of net weight, that of ${ }^{90} \mathrm{Sr}-$ in the range $0,08 \div 1,23 \mathrm{~Bq} / \mathrm{kg}$ of net weight.

2. Activity concentration of ${ }^{137} \mathrm{Cs}$ in the bones of nonpredatory fishes was in the range $0,5 \div 1,24 \mathrm{~Bq} / \mathrm{kg}$ of net weight, that of ${ }^{90} \mathrm{Sr}$ it was $0,39 \div 1,31 \mathrm{~Bq} / \mathrm{kg}$ of net weight.

3. The highest ${ }^{137} \mathrm{Cs}$ activity concentration was found in the muscles and bones of perch from the Lūkstas.

4. The highest value of ${ }^{90} \mathrm{Sr}$ activity concentration was determined in roach from the Drūkšiai $-6,5 \mathrm{~Bq} / \mathrm{kg}$ of net weight, and in the bones of perch $-4,5 \mathrm{~Bq} / \mathrm{kg}$ of net weight. 


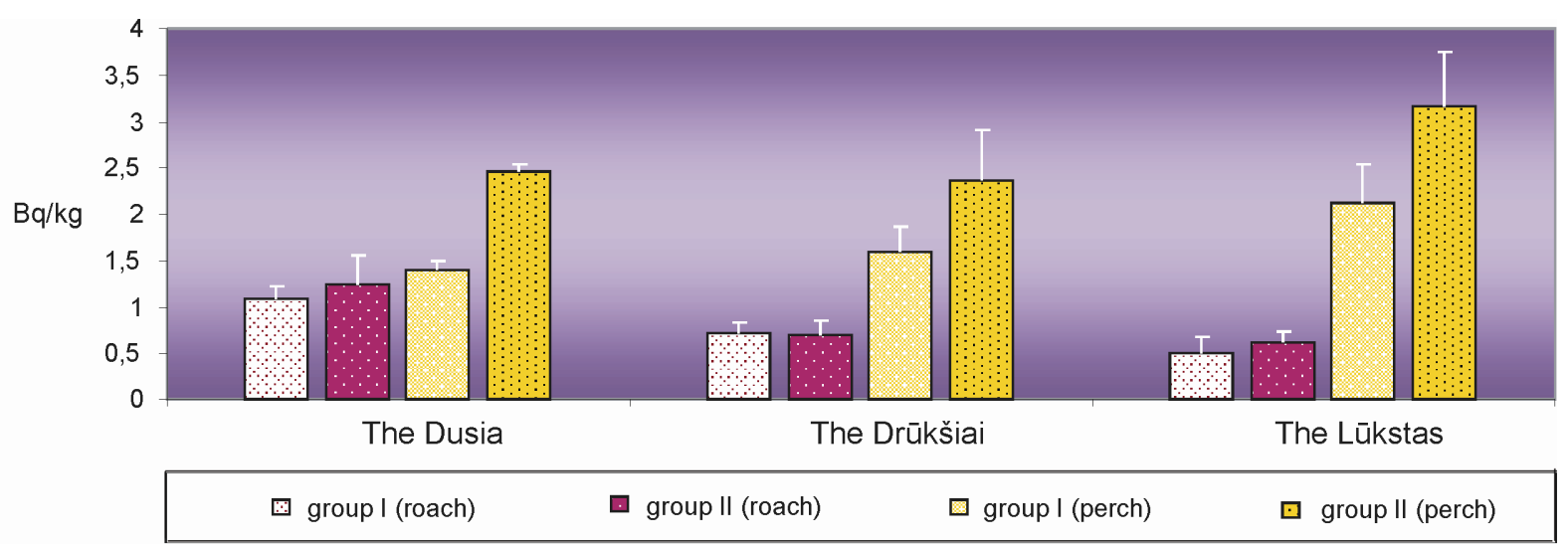

Fig 3. ${ }^{137} \mathrm{Cs}$ activity concentrations in fish muscles, Bq/kg of net weight

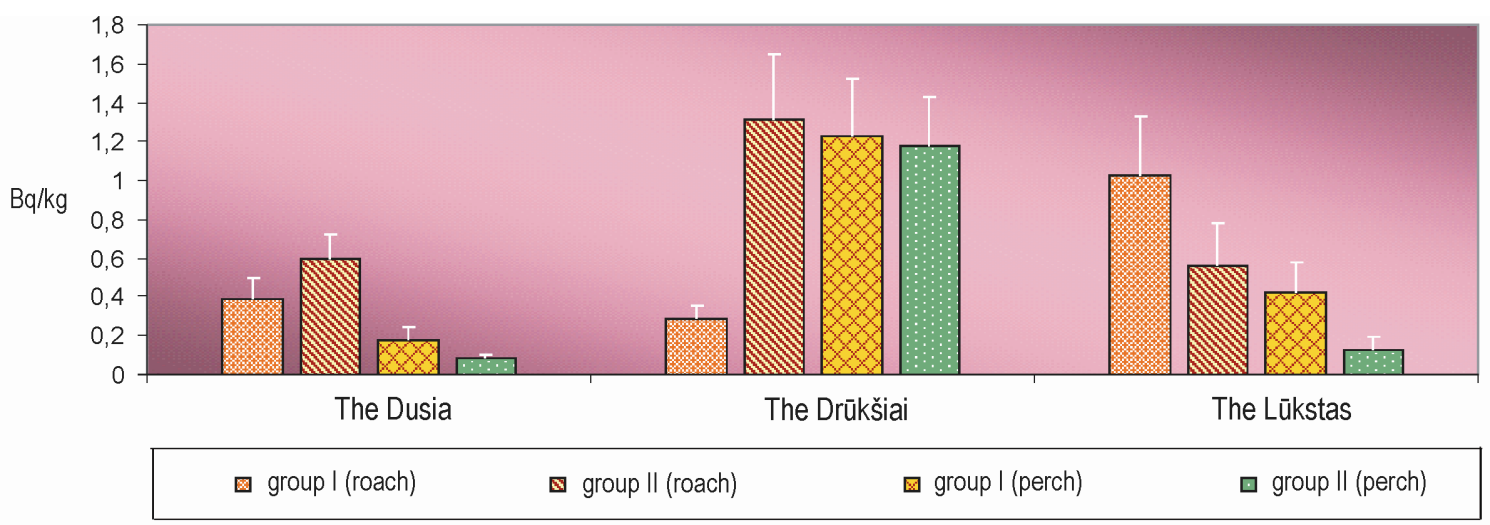

Fig 4. ${ }^{90} \mathrm{Sr}$ activity concentrations in fish muscles, $\mathrm{Bq} / \mathrm{kg}$ of net weight
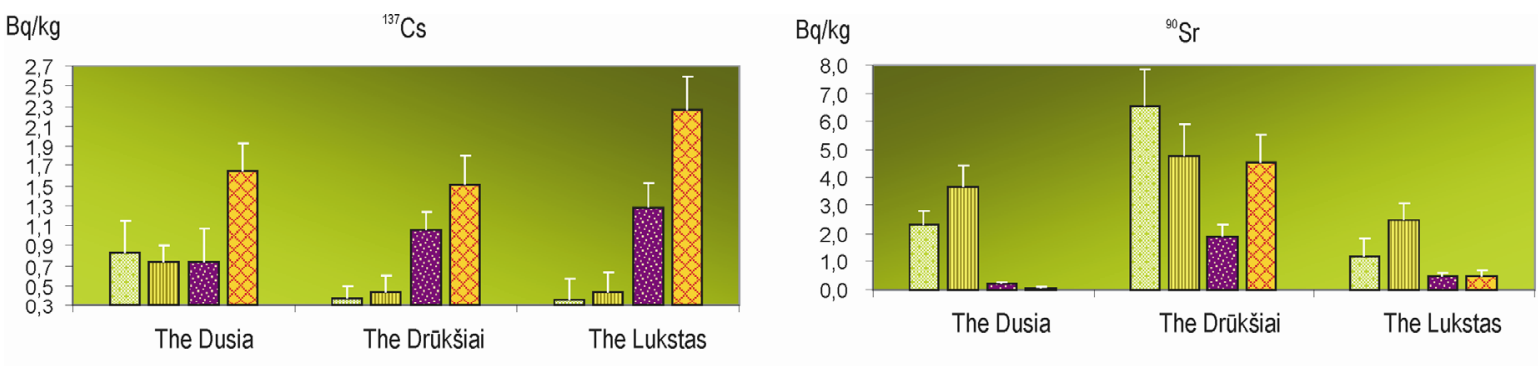

$\square$ group I (roach) 四 group II (roach) 圆 group I (perch) $\quad$ group II (perch)

Fig 5. ${ }^{137} \mathrm{Cs}$ and ${ }^{90} \mathrm{Sr}$ activity concentrations in fish bones, Bq/kg of net weight

5. ${ }^{137} \mathrm{Cs}$ activity concentration in the bones of predatory fishes was in the range $0,74 \div 2,26 \mathrm{~Bq} / \mathrm{kg}$ of net weight, and in the bones of nonpredatory fishes - in the range $0,36 \div 0,83 \mathrm{~Bq} / \mathrm{kg}$ of net weight.

6. The investigation results show that accumulation of ${ }^{137} \mathrm{Cs}$ in roach does not depend on the fish age in the case of perch, accumulation of ${ }^{137} \mathrm{Cs}$ increases with the fish age.

7. An average activity concentration of ${ }^{90} \mathrm{Sr}$ in the muscles of roach from the Drūkšiai was $1,31 \pm 0,34 \mathrm{~Bq} / \mathrm{kg}$ of net weight, and it was twice higher than in the fish samples from the lakes of Dusia and Lūkstas.

8. ${ }^{90} \mathrm{Sr}$ activity concentrations in the bones of fishes analysed are 2,5 times higher than in the muscles.
9. Radiological investigation shows that the contamination level of fish with ${ }^{137} \mathrm{Cs}$ and ${ }^{90} \mathrm{Sr}$ is not high, although possibility to be taken to the human body still exists, especially for people that eat a lot of fish.

10. Radiological monitoring in the lakes should be continued, especially in the Drūkšiai during the decommissioning of Ignalina NPP, because this lake is used for cooling, and release to the lake is possible.

\section{Acknowledgement}

Acknowledgement is given to the staff of the Laboratory of Ecology and Physiology of Hydrobionts in Institute of Ecology of Vilnius University and Radiation Protection Center for possibility to analyse fish samples from the lakes of Drūkšiai, Lūkstas and Dusia. 


\section{References}

1. Nedveckaite, T. Radiation protection in Lithuania. Vilnius: Kriventa, 2004. 239 p. (in Lithuanian).

2. Avery Simon, V. Fate of cesium in the environment: Distribution between the abiotic and biotic bomponents of aquatic and terrestrial ecosystems. J. Environ. Radioactivity, Vol 30, No 2, 1996, p 139-171.

3. Aarkrog, A. Man-made radioactive contamination of the biosphere - A 50-year retrospective. Riso National Laboratory, Denmark, 1994. 3 p.

4. Šidiškienè, D. The accident at the Chernobyl Nuclear Power Plant. Preparedness for nuclear accident in Lithuania. Health Environment (Sveikatos aplinka), Supplement No 2, Vilnius, 2001, p 1-7 (in Lithuanian).

5. Butkus, D.; Lebedyte, M. Variations of long-term contamination of Soil with ${ }^{137} \mathrm{Cs}$ in Lithuania. Health Sciences (Sveikatos mokslai), No 2, Vilnius, 2002, p 21-23 (in Lithuanian).

6. Ladygienè, R.; Butkus, D.; J. Kleiza. Estimation of change dynamics of milk contamination with ${ }^{90} \mathrm{Sr}$ and ${ }^{137} \mathrm{Cs}$ in Lithuania in 1965-2003. Journal of Environmental Engineering and Landscape Management, Vol XIII, No 1, 2005, p 9-16.

7. Butkus, D.; Laučytè, I.; Ladygienè, R. Estimation of effective dose caused by ${ }^{40} \mathrm{~K},{ }^{90} \mathrm{Sr}$ and ${ }^{137} \mathrm{Cs}$ in daily food. Journal of Environmental Engineering and Landscape Management, Vol XIV, No 2, 2005, p 77-81.

8. Morkūnas, G. Radiation Protection? It's easy. Vilnius: Kriventa, 2004. 191 p. (in Lithuanian).

9. Dušauskienè-Duž, R.; Marčiulionienè, D. Radioecological investigation of fish from the lake of Drūkšiai. In: Žuvininkysté Lietuvoje V. Vilnius, 2002, p. 199 (in Lithuanian).

10. Virbiskas, J.; Kesminas, V.; Repečka, R.; Virbickas, T. Fishes. Condition of fish population and dynamics. Natural environment of Lithuania: condition, processes and tendency. Vilnius, 1994. 87 p. (in Lithuanian).
11. Dušauskiene-Duž, R. ${ }^{90} \mathrm{Sr}$ as a lasting toxic contamination factor in a hydroecosystem. Ecology, Vol 1, 1997, p 4548 (in Lithuanian).

12. Bubinas, A.; Bukelskis, E. Fresh water hydroassociations and their methodology of investigation. Vilnius, 1986. 101 p. (in Lithuanian).

13. Kilkus, K. Limnology. Vilnius: Vilnius University Publisher, 2005 (in Lithuanian).

14. Thermal power generation and environment. Ecosystem of the wather-cooling reservoir of Ignalina Nuclear Power Plant at the initial stage of its operation. Vilnius: Academia, 1993. $262 \mathrm{p}$.

15. Ильенко, А. И. Концентрирование животными радиоизотопов и их влияние на популяцию. Москва: Наука, 1974. $165 \mathrm{c}$.

16. Правдин, И. Ф. Руководство по изучению рыб. Москва: Пищевая промышленность, 1966. 375 с.

17. Thoresson, G. Guidelines for coastal monitoring. Fishery biology. Kustrapport, 1996. 36 p.

18. LAND 36-2001. Aplinkos elementų užterštumo radionuklidais matavimas - méginiu gama spektrometrinè analizè spektrometru, turinčiu puslaidininkinį detektorių.

19. LAND 64-2005. Radioaktyvaus stroncio-90 nustatymas aplinkos elementų mėginiuose. Radiocheminis metodas.

20. Куликов, А. Н. Размерный эффект накопления ${ }^{137} \mathrm{C} 3$ рыбами из северной части Киевского водохранилища. В кн.: Радиобиологический съезд. Тезисы докладов. Пущино, 1993. 548 с.

21. Grimas, U.; Karas, P.; Neumann, G. Observation of effects on individual and population levels of perch (Perca fluviatilis L.) with high concentrations of fallout cesium. In: International Symposium on Ioning Radiation. Stockholm, 1996, p 230-231.

22. Marčiulionienè, D.; Petkevičiūte, D. Pecularities of technogenic radionuclide accumulation in freshwater fish. Ecology, Vol 3, Vilnius, 1997, p 44-47 (in Lithuanian).

23. Марей, А. Санитарная охрана водоемов от загрязнений радиоактивными веществами. Москва, 1976. $218 \mathrm{c}$.

\section{KUOJŲ IR EŠERIŲ KAI KURIUOSE LIETUVOS EŽERUOSE RADIOLOGINIAI TYRIMAI}

\section{V. Čepanko, R. L. Idzelis, V. Kesminas, R. Ladygienė}

\section{Santrauka}

Iš technogeninių radionuklidų ${ }^{90} \mathrm{Sr}$ ir ${ }^{137} \mathrm{Cs}$ priklauso biologiškai toksiškiausių radionuklidų grupei, nes santykinai mažos jų koncentracijos gali sukelti organizmų pagrindinių funkcijų sutrikimus. Žuvys - galutinè hidrosistemų trofinė grandis ir galutinè vandenų biologinė produkcija, kuri labiausiai akumuliuoja teršalus. Pagrindinis darbo tikslas - nustatyti minėtuju radionuklidų pasiskirstymo amžinius ir mitybinius dèsningumus kuojų ir ešerių audiniuose bei organuose.

Tyrimų metu nustatyta ${ }^{137} \mathrm{Cs},{ }^{90} \mathrm{Sr}$ savitasis aktyvumas žuvyse, sugautose Drūkšių, Lūksto ir Dusios ežeruose. Radioekologiškai tirta skirtingų amžiaus grupių kuojų ir ešerių raumenys bei stuburo kaulai, galva.

Drūkšių, Lūksto ir Dusios ežerų žuvų radioekologiniai tyrimai rodo, kad tirtų radionuklidų kiekis žuvyse nėra didesnis už sanitariniuose reikalavimuose nustatytas leidžiamąsias normas, tačiau nevertètų užmiršti, kad, apdorojant žuvis, ${ }^{137} \mathrm{Cs}$ ir ${ }^{90} \mathrm{Sr}$ radionuklidai, susikaupę žuvų audiniuose ir organuose, pereina į žmogaus vartojamą maistą.

Pastaruoju metu daugiausia dėmesio skiriama Ignalinos atominès elektrinès zonoje esančioms ekosistemoms tirti. Tyrimu rezultatai rodo, kad šiandien žuvų užtarša radionuklidais Drūkšiu ežere yra viena iš didžiausių. Nuolatinė radioekologinẻ stebėsena (monitoringas) būtina visuose Lietuvos regionuose.

Reikšminiai žodžiai: žuvys, Lietuva, radiologija, radionuklidai, toksiškumas, mitybinė grandis. 


\section{РАДИОЛОГИЧЕСКИЕ ИССЛЕДОВАНИЯ ОКУНЯ И ПЛОТВЫ В НЕКОТОРЫХ ОЗЕРАХ ЛИТВЫ}

\section{В. Чепанко, Р.-Л. Идзялис, В. Кясминас, Р. Ладигене}

Р ез ю м

Техногенные радионуклиды ${ }^{90} \mathrm{Sr}$ и ${ }^{137} \mathrm{Cs}$ относятся к биологически самой токсичной группе радионуклидов. Относительно небольшая их концентрация может привести к нарушению основных функций организма. Рыбы составляют заключительное трофическое звено в гидросистеме и в океано-биологической продукции, которая в наибольшей степени аккумулирует отходы хозяйственной деятельности, в том числе и радионуклиды. Целью работы было установить закономерность распределения этих радионуклидов в тканях и органах окуня и плотвы в зависимости от возраста и способа питания рыб.

Во время исследований рыб из озер Друкшяй, Лукстас и Дуся были установлены концентрации радионуклидов ${ }^{90} \mathrm{Sr}$ и ${ }^{137} \mathrm{Cs}$, содержащихся в них. Радиологическим исследованиям подвергались мышцы, кости позвоночника и головы окуня и плотвы различных возрастных групп. Исследования рыб из озер Друкшяй, Лукстас и Дуся показали, что концентрации названных радионуклидов в рыбе не превышают установленных допустимых санитарных норм. Однако следует помнить, что во время приготовления кулинарных изделий из рыбы радионуклиды ${ }^{90} \mathrm{Sr}$ и ${ }^{137} \mathrm{Cs}$, накопленные в её тканях и органах, попадают в пищу человека.

В последнее время большое внимание уделяется исследованиям экосистем, которые находятся в зоне Игналинской АЕ. Проведенные исследования показали, что рыба в Друкшяйском озере загрязнена техногенными радионуклидами не больше, чем и в других озерах (Лукстас и Дуся). Постоянные радиологические наблюдения обязательны для всех регионов Литвы.

Ключевые слова: Литва, рыба, радиология, радионуклиды, пищевая цепь, токсичность.

Violeta ČEPANKO. Master student, Dept of Environmental Protection, Vilnius Gediminas Technical University (VGTU)

Bachelor of Science (environmental engineering), VGTU. Research interests: environmental protection, protection from radiation.

Raimondas Leopoldas IDZELIS. Dr, Assoc Prof, Dept of Environmental Protection, Vilnius Gediminas Technical University (VGTU).

Doctor of Natural Sciences, 1993. Publications: author of more than 50 research papers, I study of 3 monographs. Research interests: landscape management, ecology, environmental protection, animal guide urbanization.

Vytautas KESMINAS. Dr, senior research worker, Sector of Freshwater Ecology, Laboratory of Ecology and Physiology of Hydrobionts, Dept of Aquatic Ecosystems, Institute of Ecology of Vilnius University (VU).

Research interests: ichthyology, ecology, nature protection, monitoring (investigation of fish population and communities in Lithuanian waters, including salmonid fish).

Rima LADYGIENE். Doctoral student, Dept of Environmental Protection, Vilnius Gediminas Technical University (VGTU); head of Subdivision of Radiological Investigations, Radiation Protection Centre.

First degree in Chemistry, Vilnius State V. Kapsukas University (now Vilnius University - VU), 1984. Publications: author (with co-authors) of more than 10 scientific publications. Research interests: environmental radioactivity, measurements of activity concentrations of radionuclides in food, dose assessment for public, radiation protection. 